\title{
THE IMPLEMENTATION OF AIR (AUDITORY, INTELLECTUALLY, AND REPETITION) LEARNING MODEL BASES FLASHCARD MEDIA TO IMPROVE PROBLEM SOLVING SKILL OF PLANE GEOMETRY
}

\author{
Eka Agustina Khairunnisa, Riyadi, Hasan Mahfud
}

Universitas Sebelas Maret

ekagustinakhairunnisa@gmail.com

Article History

accepted 09/07/2018

approved 01/08/2018

published 17/09/2018

\section{Keywords}

Problem solving skill,

Flashcard media,

Auditory Intellectually and

Repetition (AIR)

\begin{abstract}
The purpose of this research is to improve problem solving skill of plane geometry by applying Auditory Intellectually and Repetition (AIR) learning model bases Flashcard in the fifth grade students of State Elementary School Mangkubumen Kulon No.83 in academic year 2017/2018. This form of research is a Classroom Action Research and it was conducted three cycles. Each cycle consists of four steps there are planning, action, observation, and reflection. Data collection techniques are using tests, observations, interviews and documentation. Data validity tests are using content validity and triangulation. Data analysis technique used is the interactive model. The result of the assessment of study activity and teacher performance appraisal also increase. Based on the result of the research, it can be concluded that through the application of Auditory Intellectually and Repetition (AIR) learning model bases Flashcard can improve improve problem solving skill of plane geometry for $V$ grade students of SD N Surakarta in the academic year 2017/2018.
\end{abstract}

Social, Humanities, and Education Studies (SHEs): Conference Series https://jurnal.uns.ac.id/shes 


\section{PENDAHULUAN}

Matematika merupakan salah satu unsur penting yang digunakan dalam penelitian. Hal ini dikarenakan matematika merupakan sumber ilmu bagi ilmu lain, khususnya ilmu eksak. Matematika adalah salah satu mata pelajaran yang selalu diajarkan di semua jenjang pendidikan, mulai dari sekolah dasar, sekolah menengah pertama, sekolah menengah atas hingga perguruan tinggi. Salah satu materi dalam pembelajaran matematika SD yang dianggap sulit oleh siswa adalah menyelesaikan soal cerita.

Kesulitan menyelesaikan soal cerita yang dialami siswa perlu diatasi. Siswa tidak hanya harus mampu dalam menyelesaikan soal cerita melainkan terampil. Keterampilan menyelesaikan soal cerita matematika perlu ditingkatkan khususnya pada materi bangun datar. Hal ini diperlukan, karena materi ini sering muncul dalam soal ujian dan tergolong soal yang sulit bagi siswa. Oleh karena itu, pentingnya keterampilan menyelesaikan soal cerita bangun datar perlu disampaikan dan ditingkatkan. Namun kenyataannya keterampilan menyelesaikan soal cerita bangun datar kelas V SDN Surakarta masih rendah.

Rendahnya keterampilan menyelesaikan soal cerita bangun datar siswa kelas $\mathrm{V}$ dibuktikan dari hasil dokumentasi, hasil wawancara, hasil observasi, dan hasil tes pratindakan. Data dari hasil wawancara guru pada tanggal 24 November 2017 menunjukkan bahwa: 1) Pelajaran matematika dianggap sulit oleh siswa; 2) guru belum mengunakan model pembelajaran yang inovatif; 3) antusias siswa dalam pembelajaran masih kurang. Sedangkan data dari hasil wawancara dengan siswa pada tanggal 24 November 2017 diperoleh hasil: 1) Materi soal cerita bangun datar dianggap sulit oleh siswa, karena siswa belum memahami rumus untuk meghitung luas dan keliling bangun datar serta langkah-langkah dalam menyelesaikan soal cerita; 2) guru belum mengunakan model pembelajaran yang inovatif.

Dari hasil observasi kinerja guru yang dilakukan pada tanggal 24 November 2017. Hasil observasi kinerja guru menunjukkan kriteria baik yaitu dengan skor 2,92 (Skor 2,00-3,00 dikategorikan kinerja guru dalam pembelajaran baik). Sedangkan skor aktivitas siswa temasuk kedalam kategori kurang baik yaitu 1,75 (Skor 1,00-1,70 dikategorikan aktivitas siswa dalam pembelajaran kurang baik). Dari data tersebut dapat dilihat bahwa guru sudah menjelaskan materi dengan baik namun kondisi siswa dalam pembelajaran tidak sepenuhnya baik. Siswa masih belum bisa menangkap maksud pembelajaran yang disampaikan oleh guru dengan baik. Data yang diperoleh hasil tes pratindakan pada materi menyelesaikan soal cerita bangun datar diperoleh persentase ketuntasan klasikal sebesar 20,83\% atau 5 dari 24 siswa yang mencapai KKM (KKM $\geq 70)$. Siswa belum memahami betul cara menyelesaikan soal cerita bangun datar. Hal ini mengakibatkan siswa kesulitan untuk mengerjakan soal cerita bangun datar.

Terkait belum optimalnya keterampilan menyelesaikan soal cerita bangun datar kelas V SD N Surakarta, maka peneliti menerapkan model pembelajaran Auditory, Intellectually and Repetition $(A I R)$ berbasis media Flashcard sebagai salah satu alternatif untuk meningkatkan keaktifan dan partisipasi siswa dalam pembelajaran matematika. Huda (2014) model pembelajaran Auditory, Intellectually, and Repetition (AIR) merupakan salah satu model pembelajaran yang menggunakan pendekatan berfikir dan berbasis masalah yang memperhatikan tiga hal yaitu Auditory (belajar dengan berbicara dan mendengar), Intellectually (belajar dengan memecahkan masalah dan merenung), dan Repetition (pengulangan kembali). Peneliti mengolaborasikan model pembelajaran AIR dengan media Flashcard. Media Flashcard merupakan kartu kecil yang dapat berisi gambar, teks, atau tanda simbol yang menuntun siswa kepada sesuatu yang berhubungan dengan keterangan yang ada pada kartu. 
Model AIR berbasis media Flashcard diterapkan karena, model AIR memberikan kesempatan yang lebih banyak pada siswa dalam memanfaatkan pengetahuan dan keterampilan secara komprehensif melalui pengalamannya dalam menemukan solusi untuk memecahkan suatu masalah, dalam hal ini masalah yang dipecahkan yaitu soal cerita bangun datar. Ciri khusus model pembelajaran AIR yaitu adanya tahap pengulangan (repetition). Pada tahap tersebut siswa diberikan pengulangan berupa soal cerita yang diberikan dalam bentuk kuis secara individu. Dengan ini, siswa dapat meningkatkan daya ingatnya mengenai rumus menghitung luas dan keliling bangun datar dan juga langkah-langkah dalam menyelesaikan soal cerita matematika. Penggunaan media Flashcard menambah daya tarik siswa untuk memahami materi yang disampaikan, karena media tersebut digunakan dalam bentuk permainan (Setiawati, 2015).

\section{METODE}

Penelitian ini dilaksanakan pada siswa kelas V SD N Surakarta tahun pelajaran 2017/2018 dalam kurun waktu delapan bulan dimulai dari bulan November 2017 hingga Mei 2018. Data yang dikumpulkan dalam penelitian ini berupa hasil observasi kinerja guru dan aktivitas siswa, hasil wawancara dengan guru dan siswa, hasil tes pratindakan dan hasil tes pada setiap petemuan pada siklus I, II dan III, serta dokumentasi selama proses pembelajaran. Sumber data dalam penelitian ini yaitu sumber data primer dan sekunder. Teknik pengumpulan data yang digunakan yaitu observasi, wawancara, tes, dan dokumentasi. Validitas data yang digunakan yaitu validitas isi, triangulasi sumber dan teknik. Data yang diperoleh dalam penelitian ini dianalisis menggunakan model interaktif Milles dan Huberman yang dilakukan dalam 3 siklus dengan masing-masing siklus terdiri atas 2 pertemuan. Setiap siklus terdiri dari empat tahap yaitu perencanaan, tindakan, observasi dan refleksi.

\section{HASIL DAN PEMBAHASAN}

Berdasarkan hasil tes pratindakan keterampilan menyelesaikan soal cerita bangun datar sebelum diterapkannya model pembelajaran Auditory, Intellectually and Repetition $(A I R)$ berbasis media Flashcard menunjukkan bahwa sebagian besar siswa kelas V SD N Surakarta tahun pelajaran 2017/2018 masih memperoleh nilai di bawah KKM ( $\geq 70)$. Hasil selengkapnya dapat dilihat pada Tabel 1 sebagai berikut: 
Tabel 1. Distribusi Frekuensi Nilai Keterampilan Menyelesaikan Soal Cerita Bangun Datar pada Pratindakan

\begin{tabular}{|c|c|c|c|c|c|}
\hline No. & Interval & $\begin{array}{l}\text { Frekuensi } \\
\text { (fi) }\end{array}$ & $\begin{array}{l}\text { Nilai tengah } \\
\text { (xi) }\end{array}$ & fi.xi & $\begin{array}{c}\text { Presentase } \\
(\%)\end{array}$ \\
\hline 1. & $12-23$ & 4 & 17,5 & 70 & 16,7 \\
\hline 2. & $24-35$ & 4 & 29,5 & 118 & 16,7 \\
\hline 3. & $36-47$ & 8 & 41,5 & 332 & 33,3 \\
\hline 4. & $48-59$ & 3 & 53,5 & 160,5 & 12,5 \\
\hline 5. & $60-71$ & 3 & 65,5 & 196,5 & 12,5 \\
\hline 6. & $72-83$ & 2 & 77,5 & 155 & 8,3 \\
\hline \multirow{2}{*}{\multicolumn{3}{|c|}{\begin{tabular}{c|c} 
Jumlah & 24 \\
\multicolumn{2}{c}{ Skor rata-rata }
\end{tabular}}} & 285 & 1032 & 100 \\
\hline & & & \multicolumn{3}{|c|}{42,77} \\
\hline \multicolumn{4}{|c|}{ Ketuntasan klasikal } & \multicolumn{2}{|c|}{$20,83 \%$} \\
\hline \multicolumn{4}{|c|}{ Nilai tertinggi } & \multicolumn{2}{|c|}{73,8} \\
\hline \multicolumn{4}{|c|}{ Nilai terendah } & \multicolumn{2}{|c|}{13,8} \\
\hline
\end{tabular}

Berdasarkan data di atas, sebagian besar siswa belum mencapai kriteria ketuntasan minimal yang telah ditetapkan yaitu 70. Dari 24 siswa, 19 hanya 5 siswa atau 20,83\% siswa yang mencapai kriteria ketuntasan minimal. Dengan nilai terendah 13,8 , nilai tertinggi 73,8 , dan nilai rata-rata kelas 42,77.

Setelah penerapan model pembelajaran Auditory, Intellectually and Repetition $(A I R)$ berbasis media Flashcard dalam pembelajaran, nilai keterampilan menyelesaikan soal cerita bangun datar pada siklus I mengalami peningkatan. Hasilnya dapat dilihat pada Tabel 2 sebagai berikut:

Tabel 2. Distribusi Frekuensi Rata-rata Nilai Keterampilan Menyelesaikan Soal Cerita Bangun Datar Siklus I

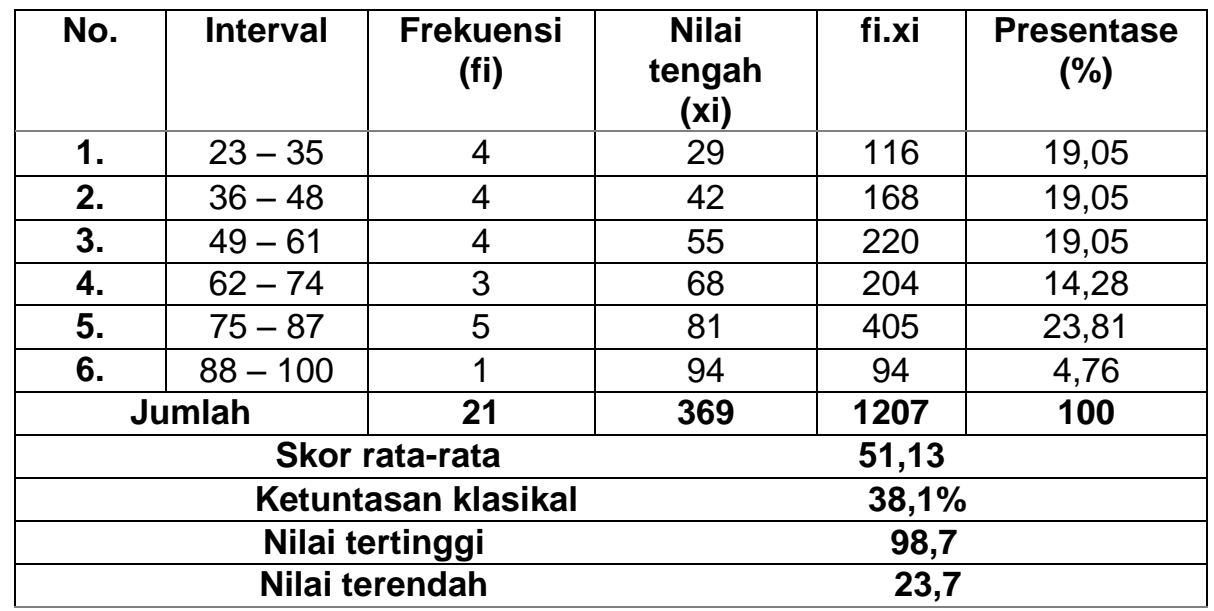

Pada siklus I diperoleh nilai rata-rata 51,13 . Ketuntasan klasikal yang dicapai sebesar $38,1 \%$ atau 8 siswa yang mendapat nilai mencapai KKM $(\geq 70)$. Nilai terendah 23,7 dan nilai tertinggi 98,7. Berdasarkan data tersebut dapat diketahui bahwa ketuntasan klasikal pada siklus I belum mencapai target pada indikator kinerja yaitu $85 \%$, maka penelitian dilanjutkan pada siklus II.

Pada siklus II nilai keterampilan menyelesaikan soal cerita bangun datar pada siswa kelas V SD Negeri Mangkubumen Kulon No.83 Surakarta, tahun ajaran 2017/2018 menunjukkan adanya peningkatan kembali. Hasil selengkapnya dapat dilihat pada Tabel 3. sebagai berikut: 


\section{Tabel 3. Distribusi Frekuensi Rata-rata Nilai Keterampilan Menyelesaikan Soal Cerita Bangun Datar Siklus II}

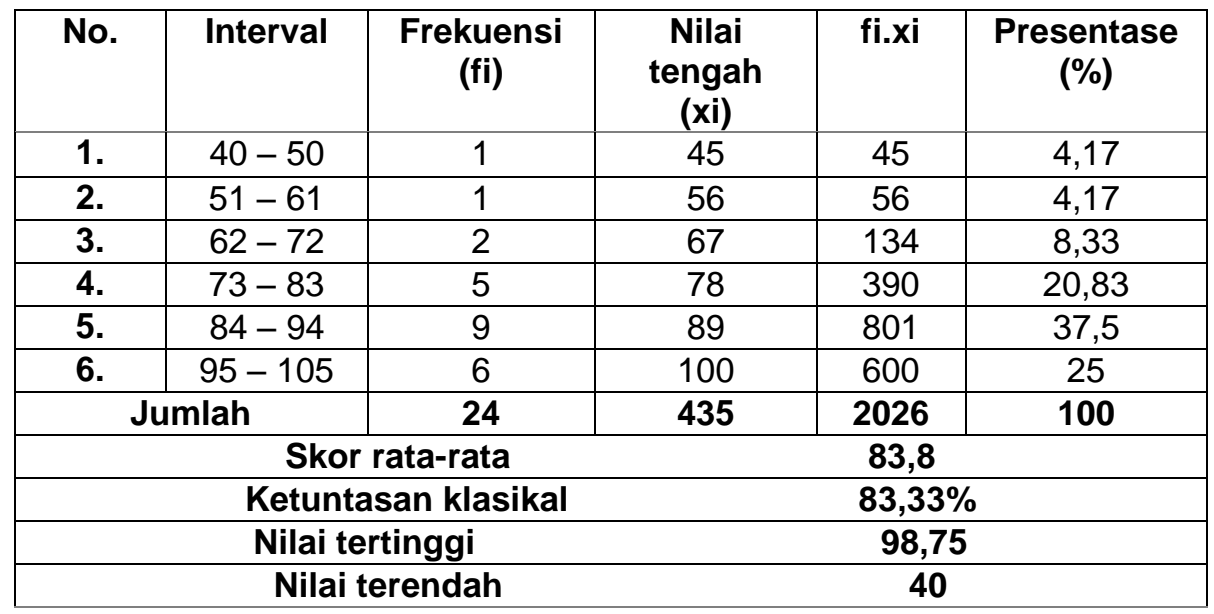

Setelah dilaksanakan tindakan siklus II data yang diperoleh menunjukkan bahwa nilai rata-rata kelas mencapai 83,8 . Ketuntasan klasikal yang dicapai sebesar $83,33 \%$ atau 20 siswa mendapatkan nilai mencapai KKM $(\geq 70)$. Nilai terendah 40 dan nilai tertinggi 98,75 . Hasil nilai keterampilan menyelesaikan soal cerita bangun datar pada siklus II mengalami peningkatan pada nilai rata-rata. Guna mencapai indikator kinerja yang telah ditetakan yaitu $85 \%$, maka penelitian dilanjutkan pada siklus III.

Pada siklus III nilai keterampilan menyelesaikan soal cerita bangun datar menunjukkan adanya peningkatan kembali. Hasil selengkapnya dapat dilihat pada Tabel 4. Sebagai berikut:

\section{Tabel 4. Distribusi Frekuensi Rata-rata Nilai Keterampilan Menyelesaikan Soal Cerita Bangun Datar Siklus III}

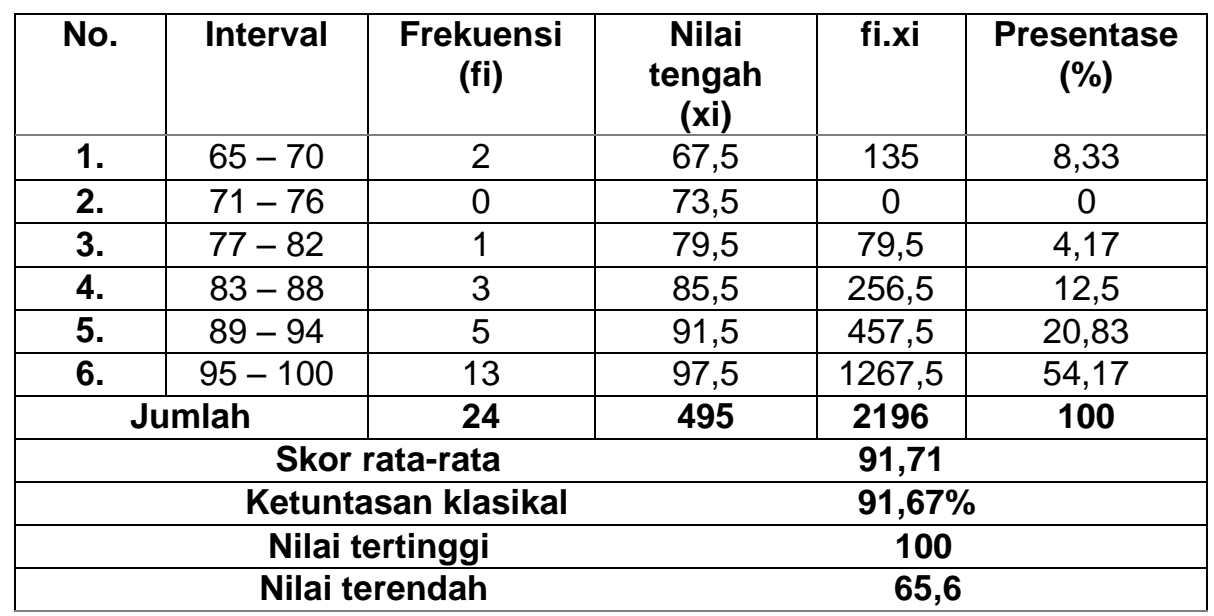

Setelah dilaksanakan tindakan siklus III data yang diperoleh menunjukkan bahwa rata-rata kelas mencapai 91,71. Ketuntasan klasikal mencapai 91,67\% atau 22 siswa mendapatkan nilai di atas $\mathrm{KKM}(\geq 70)$, dengan nilai terendah 65,6 dan nilai tertinggi 100 . Hasil nilai keterampilan menyelesaikan soal cerita bangun datar pada siklus III meningkat dan telah melebihi indikator kinerja yaitu 85\% siswa mencapai batas KKM 
$\geq 70$, oleh karena itu peneliti mengakhiri tindakan dalam pembelajaran menyelesaikan soal ceria bangun datar.

Pada tes pratindakan keterampilan menyelesaikan soal cerita bangun datar, diperoleh nilai rata-rata kelas 42,77 , masih kurang dari yang telah ditetapkan yaitu $\geq 70$. Sedang besarnya persentase siswa yang nilainya tuntas hanya $20,83 \%$ atau 5 siswa, sedangkan 66,67\% atau 19 siswa lainnya masih belum memenuhi KKM. Nilai terendah pada tes pratindakan yaitu 13,8 , sedangkan nilai tertinggi yang diperoleh adalah 73,8 . Berdasarkan hasil analisis tes pratindakan tersebut, indikator kinerja (85\% atau 20 siswa) belum tercapai, maka dilakukan tindakan yang berupa penelitian tindakan kelas untuk meningkatkan keterampilan menyelesaikan soal cerita bangun datar dengan menggunakan model pembelajaran Auditory, Intellectually and Repetition (AIR) berbasis media Flashcard.

Pembelajaran siklus I menerapkan model pembelajaran Auditory, Intellectually and Repetition (AIR) berbasis media Flashcard dalam pembelajaran menyelesaikan soal cerita bangun datar. Hasil analisis data nilai pada siklus I menunjukkan bahwa persentase hasil tes siswa yang tuntas yaitu $38,1 \%$ atau 8 siswa mendapat nilai mencapai KKM, nilai rata-rata kelas meningkat menjadi 51,13. Hasil analisis pada siklus II menunjukkan adanya peningkatan kembali. Nilai ketuntasan klasikal mencapai $83,33 \%$ atau 20 siswa mendapat nilai mencapai KKM dengan nilai rata-rata kelas sebesar 83,8 . Pada siklus III terjadi peningkatan kembali yaitu, ketuntasan klasikal mencapai $91,67 \%$ atau 22 siswa mendapat nilai mencapai KKM dengan nilai rata-rata kelas sebesar 91,71 .

Selain peningkatan pada keterampilan menyelesaikan soal cerita bangun datar pada siswa kelas $\mathrm{V}$, kinerja guru dan aktivitas siswa juga mengalami peningkatan. Pada siklus I kinerja guru termasuk kategori baik dengan skor rata-rata yaitu 2,9. Pada siklus II kinerja guru termasuk dalam kategori sangat baik dengan skor rata-rata yaitu 3,24. Pada siklus III kinerja guru termasuk dalam kategori sangat baik dengan skor rata-rata yaitu 3,5. Sehingga dapat disimpulkan bahwa kinerja guru terus meningkat pada setiap pertemuan. Sehingga hal ini menunjukkan bahwa suasana pembelajaran yang berjalan kondusif dan siswa berpartisipasi secara aktif. Jika dibandingkan dengan kinerja guru sebelum tindakan, hasil kinerja guru mengalami kemunduran pada siklus I namn pada siklus selanjutnya mengalami peningkatan. Pada pratindakan guru sudah mengajar dengan baik namun guru kurang melibatkan siswa secara aktif dalam pembelajaran sehingga siswa terkesan bosan. Guru juga belum menggunakan media dalam mengajar.

Peningkatan aktivitas siswa terus bertambah dengan menggunakan model pembelajaran AIR berbasis media Flashcard. Pada siklus I aktivitas siswa termasuk dalam kategori yang baik dengan skor rata-rata yaitu 2. Pada siklus II aktivitas siswa termasuk dalam kategori baik yaitu 2,11 dan pada siklus III tergolong baik yaitu 2,48. Berdasarkan hasil tersebut menunjukkan bahwa siswa menjadi lebih aktif dan antusias untuk ikut berpartisipasi dalam pembelajaran. Fakta ini juga diungkapkan Shoimin (2016) berpendapat model pembelajaran AIR dapat memungkinkan siswa untuk lebih sering berpartispasi aktif dalam pembelajaran. Selain itu, siswa memiliki kesempatan untuk memanfaatkan pengetahuan dan keterampilan yang dimilikinya. Indriana (2011) media Flashcard memiliki kelebihan yaitu, praktis dalam pembuatan dan penggunaannya, mudah diingat dan menyenangkan.

Pada hasil penelitian terdapat perbedaan yang signifikan antara nilai keterampilan menyelesaikan soal cerita bangun datar sebelum dan sesudah diterapkannya model pembelajaran Auditory, Intellectually and Repetition (AIR) berbasis media Flashcard. Hal ini juga didukung dengan pendapat yang disampaikan oleh Shoimin (2016: 30) bahwa model AIR memberikan kesempatan yang lebih banyak dalam memanfaatkan pengetahuan dan keterampilan secara komprehensif melalui pengalamannya dalam menemukan solusi untuk memecahkan suatu masalah, dalam 
hal ini masalah yang dipecahkan yaitu soal cerita bangun datar. Ciri khusus model pembelajaran AIR yaitu adanya tahap pengulangan (repetition). Pada tahap tersebut siswa diberikan pengulangan berupa soal cerita yang diberikan dalam bentuk kuis secara individu. Dengan ini siswa dapat meningkatkan daya ingatnya mengenai rumus menghitung luas dan keliling bangun datar dan juga langkah-langkah dalam menyelesaikan soal ceritanya.

Penggunaan media Flashcard memungkinkan siswa tertarik untuk memahami materi yang disampaikan, karena media tersebut digunakan dalam bentuk permainan (Setiawati, 2015). Peningkatan tersebut juga sejalan dengan penelitian yang dilakukan oleh Hasnawati, Ikman dan Astuti Sari (2016) bahwa penerapan model pembelajaran AIR dapat meningkatkan hasil pembelajaran matematika. Selain itu peningkatan juga terjadi dengan penelitian yang dilakukan oleh Anggraini Febraningrum (2017) bahwa penerapan media pembelajaran Flashcard dapat meningkatkan keterampilan berhitung pecahan.

\section{SIMPULAN}

Berdasarkan hasil penelitian tindakan kelas yang telah dilaksanakan selama tiga siklus dapat disimpulkan bahwa model pembelajaran Auditory, Intellectually and Repetition $(A I R)$ berbasis media Flashcard dapat meningkatkan keterampilan menyelesaikan soal cerita bangun datar pada siswa kelas V SD N Surakarta tahun pelajaran 2017/2018.

\section{DAFTAR PUSTAKA}

Huda, Miftahul. (2014). Model-model Pengajaran dan Pembelajaran. Yogyakarta: Pustaka Pelajar

Indriana, Dina. (2011). Ragam Alat Bantu Media Pengajaran. Yogkarta: Diva Press.

Setiawati, Ni Luh Made., dkk. (2015). "Pengaruh Penggunaan Media Flashcard terhadap Minat dan Hasil Belajar IPA Peserta Didik Kelas VI SDLBB Negeri Tabanan. (hal. 1-10). Bali: Program Studi Penelitian dan Evaluasi Pendidikan, Program Pascasarjana Universitas Pendidikan Ganesha.

Shoimin A. (2014). 68 Model Pembelajaran Inovatif dalam Kurikulum 2013. Yogjakarta: Ar-Ruzz Media. 